\title{
Carnitine/organic cation transporter OCTN2-mediated transport of carnitine in primary-cultured epididymal epithelial cells
}

\author{
Daisuke Kobayashi ${ }^{1,2}$, Masanori Irokawa ${ }^{1}$, Tomoji Maeda ${ }^{1}$, Akira Tsuji ${ }^{2}$ and Ikumi Tamai ${ }^{*}$ \\ ${ }^{1}$ Faculty of Pharmaceutical Sciences, Tokyo University of Science, 2641 Yamasaki, Noda, Chiba 278-8510, Japan \\ and ${ }^{2}$ Faculty of Pharmaceutical Sciences, Kanazawa University, Kakuma, Kanazawa 920-1192, Japan
}

Correspondence should be addressed to I Tamai; Email: tamai@rs.noda.tus.ac.jp

\begin{abstract}
Carnitine is essential for the acquisition of motility and maturation of spermatozoa in the epididymis, and is accumulated in epididymal fluid. In this study, carnitine transport into primary-cultured rat epididymal epithelial cells was characterized to clarify the nature of the transporter molecules involved. Uptake of carnitine by primary-cultured epididymal epithelial cells was time, $\mathrm{Na}^{+}$and concentration dependent. Kinetic analysis of carnitine uptake by the cells revealed the involvement of high- and low-affinity transport systems with $\mathrm{Km}$ values of $21 \mu \mathrm{M}$ and $2.2 \mathrm{mM}$ respectively. The uptake of carnitine by the cells was significantly reduced by inhibitors of carnitine/organic cation transporter (OCTN2), such as carnitine analogues and cationic compounds. In RT-PCR analysis, OCTN2 expression was detected. These results demonstrated that the high-affinity carnitine transporter OCTN2, which is localized at the basolateral membrane of epididymal epithelial cells, mediates carnitine supply into those cells from the systemic circulation as the first step of permeation from blood to spermatozoa.

Reproduction (2005) 130 931-937
\end{abstract}

\section{Introduction}

Spermatozoa produced in the testis travel along the epididymis to the vas deferens, and acquire motility and fertilizing ability during their passage through the epididymis. The maturing spermatozoa are protected by the bloodepididymis barrier, which is constituted from epididymal epithelial cells (Hinton et al. 1995). This barrier controls the luminal fluid environment, which is different in composition from the blood plasma (Brooks et al. 1974, Hinton \& Palladino 1995). Carnitine, which is an essential cofactor for fatty acid metabolism, is present in epididymal plasma and spermatozoa at a concentration of 1-63 mM (Marquis \& Fritz 1965, Casillas 1972, Hinton et al. 1979, Jeulin \& Lewin 1996), while the blood plasma concentration is only about $50 \mu \mathrm{M}$, and carnitine is believed to play an important role(s) in sperm maturation (Casillas \& Chaipayungpan 1979) and motility (Hinton et al. 1981) in the epididymis. Carnitine concentration is reduced in the seminal fluid of infertile patients (Matalliotakis et al. 2000), and improvements in sperm motility and viability of spermatozoa can be obtained by treatment with carnitine and acetylcarnitine (Vicari \& Calogero 2001). Since the carnitine concentration in the epididymal fluid can reach more then 1000 times that in the blood, active transport mechanisms through epididymal epithelial cells into the lumen are assumed to operate (Bremer
1983). The presence of systems promoting carnitine permeation across epididymal epithelial cells has been reported (Yeung et al. 1980, Cooper et al. 1986, Radigue et al. 1996). In addition, it was found that carnitine uptake in dispersed epididymal cells was saturable and the Michaelis constant $(\mathrm{Km})$ value for carnitine was $927 \mu \mathrm{M}$ (James et al. 1981).

In mammals, several carnitine transporters have been isolated and characterized. We have reported that carnitine/organic cation transporter (OCTN) 1 and OCTN2 in humans and mice and OCTN3 in mice transport carnitine (Tamai et al. 1998, 2000, Yabuuchi et al. 1999). OCTN2 is an $\mathrm{Na}^{+}$-dependent, high-affinity (Michaelis constant $(\mathrm{Km})=4-25 \mu \mathrm{M})$ carnitine transporter (Sekine et al. 1998, Tamai et al. 1998, 2000, Wu et al. 1999), which serves to maintain the concentration of carnitine in serum by functioning as a reabsorption transporter of carnitine that is eliminated from the blood stream by glomerular filtration (Nezu et al. 1999, Yokogawa et al. 1999, Tamai et al. 2001). It has been reported that human and mouse OCTN1 transport carnitine (Yabuuchi et al. 1999, Tamai et al. 2000), while rat OCTN1 does not exhibit carnitine transport activity (Wu et al. 2000). Human carnitine transporter CT2 and mouse OCTN3, which are present selectively in male reproductive tissues (Tamai et al. 2000, Enomoto et al. $2002)$, transport carnitine with high affinity $(K m=20 \mu \mathrm{M}$ and $3 \mu \mathrm{M}$ respectively) in a sodium-independent manner. 
In addition, Nakanishi et al. (2001) reported that the $\mathrm{Na}^{+}$and $\mathrm{Cl}^{-}$-coupled neutral and cationic amino acid transporter $\mathrm{ATB}^{0,+}$ can transport carnitine with low affinity $(K \mathrm{~m}=0.83 \mathrm{mM})$. OCTN2 may be the prime candidate for the major transporter, since it is localized at the basolateral membrane of epididymal epithelial cells (Rodrígez et al. 2002) and OCTN2-deficient juvenile visceral steatosis (jvs) mice show male infertility with epididymal dysfunction (Toshimori et al. 1999).

In the present study, we examined the mechanism of carnitine transport in epididymal epithelial cells by using primary-cultured, rat epididymal epithelial cells, focusing on the involvement of OCTN2 as the major transporter.

\section{Materials and Methods}

\section{Materials}

$\mathrm{L}-\left[{ }^{3} \mathrm{H}\right]$ carnitine $(80.0 \mathrm{Ci} / \mathrm{mmol})$ was purchased from Amersham Biosciences Corp. Collagenase and trypsin were obtained from Sigma Chemical Co. and Becton Dickinson Microbiology Systems (Sparks, MD, USA) respectively. All other reagents, unless otherwise noted, were purchased from Sigma Chemical Co. or Wako Pure Chemical Industries Co. (Osaka, Japan).

\section{Preparation and primary culture of rat epididymal epithelial cells}

Epididymal epithelial cells were isolated from 5-week-old Sprague-Dawley rats (Saitama Experimental Animal Supply Co. Ltd, Saitama, Japan) according to the method reported previously (Kierszenbaum et al. 1981, Leung et al. 2001). To minimize contamination of non-epithelial cells and inhibition of attachment of epithelial cells to culture dishes by spermatozoa, we used immature rats, which do not contain spermatozoa (Kierszenbaum et al. 1981, Leung et al. 2001). Briefly, epididymides were dissected out and minced into small fragments. These fragments were transferred into $0.25 \%$ trypsin (Type II; Sigma Chemical Co.) in Hank's balanced salt solution (HBSS, $\mathrm{pH}$ 7.6) and incubated at $32.5^{\circ} \mathrm{C}$ for $30 \mathrm{~min}$ with shaking (60 cycles/min). The sample was centrifuged ( $800 \mathrm{~g}$ for $5 \mathrm{~min}$ ). The resultant pellet was suspended in $0.1 \%$ collagenase I in HBSS $(\mathrm{pH}$ 7.6) and incubated at $32{ }^{\circ} \mathrm{C}$ for $60 \mathrm{~min}$ with shaking $(60$ cycles/min). The sample was allowed to settle for $5 \mathrm{~min}$, then the supernatant was removed and the sediment was suspended in Eagle's minimal essential medium (EMEM) supplemented with $0.1 \mathrm{mM}$ non-essential amino acids, $1 \mathrm{mM}$ sodium pyruvate, $4 \mathrm{mM}$ glutamine, $1 \mathrm{nM} 5 \alpha$-dihydrotestosterone, 10\% fetal bovine serum, 100 units/ml benzylpenicillin and $100 \mu \mathrm{g} / \mathrm{ml}$ streptomycin. The resultant cell suspension was filtered through four sheets of gauze. Isolated epididymal cells were plated in tissue culture dishes at $5 \times 10^{5}$ cells $/ \mathrm{ml}$ and incubated at $32.5^{\circ} \mathrm{C}$ for $10 \mathrm{~h}$. Contaminating fibroblasts and smooth muscle cells became attached to the dishes within $10 \mathrm{~h}$, so that epididymal epithelial cells could be separated from nonepithelial cells (Kierszenbaum et al. 1981). The supernatant containing epididymal epithelial cells was collected and transferred to new dishes at $1 \times 10^{5}$ cells $/ \mathrm{cm}^{2}$. Epididymal epithelial cells were cultured at $32.5^{\circ} \mathrm{C}$ in supplemented EMEM for 4-5 days and supplemented EMEM was renewed daily. Cultured epididymal epithelial cells were used for RT-PCR analysis and for transport studies. More than $80 \%$ of the cells were epithelial cells as judged from immunocytochemistry with anti-pan cytokeratin antibody (AE1/AE3; BIOCARTA, San Diego, CA, USA).

\section{Carnitine transport experiments}

Uptake of carnitine in suspended primary-cultured rat epididymal epithelial cells was examined using the same method as in a previous study with primary-cultured Sertoli cells (Kato et al. 2005, Kobayashi et al. 2005). Briefly, primary-cultured epididymal epithelial cells were harvested with a cell scraper and suspended in transport medium containing $137 \mathrm{mM} \mathrm{NaCl}, 5 \mathrm{mM} \mathrm{KCl}, 0.39 \mathrm{mM}$ $\mathrm{NaHCO}_{3}, 0.44 \mathrm{mM} \mathrm{KH_{2 }} \mathrm{PO}_{4}, 0.95 \mathrm{mM} \mathrm{CaCl}, 0.8 \mathrm{mM}$ $\mathrm{MgSO}_{4}, 25 \mathrm{mM}$ D-glucose and $10 \mathrm{mM}$ HEPES, adjusted to $\mathrm{pH}$ 7.4. The cell suspension was preincubated at $32.5^{\circ} \mathrm{C}$ for $20 \mathrm{~min}$ in the transport medium, then centrifuged, and the resultant cell pellets were re-suspended in $200 \mu \mathrm{l}$ transport medium containing $\left[{ }^{3} \mathrm{H}\right]$ carnitine to initiate the uptake. At an appropriate time, the cell suspension was diluted with $800 \mu \mathrm{l}$ ice-cold transport medium and centrifuged immediately (7000 $\mathrm{g}$ for $1 \mathrm{~min}$ ) to terminate the uptake reaction. The cells were then resuspended in icecold transport medium and obtained as the pellet after centrifugation. The resultant cell pellets were solubilized in $1 \mathrm{M} \mathrm{NaOH}$ and the cell-associated radioactivity was measured with a liquid scintillation counter (Aloka, Tokyo, Japan) using Cleasol-1 (Nacalai tesque, Kyoto, Japan) as a liquid scintillation fluid. $\mathrm{Na}^{+}$-free transport medium was prepared by replacing $137 \mathrm{mM} \mathrm{NaCl}$ and $0.39 \mathrm{mM} \mathrm{NaHCO}_{3}$ in the standard transport medium with $137 \mathrm{mM}$ lithium $\mathrm{Cl}, 137 \mathrm{mM} \mathrm{KCl}$ or $137 \mathrm{mM}$ choline $\mathrm{Cl}$ and $0.39 \mathrm{mM} \mathrm{KHCO}_{3}$ respectively, and was used to assess the uptake in the absence of sodium ion.

$\left[{ }^{3} \mathrm{H}\right]$ Carnitine uptake was usually calculated as observed uptake minus non-saturable uptake, which was taken to be the uptake of $\left[{ }^{3} \mathrm{H}\right]$ carnitine in the presence of $20 \mathrm{mM}$ unlabeled carnitine.

\section{RNA isolation and RT-PCR}

Total RNA was extracted from cultured cells with the ISOGEN RNA extraction solution (Wako Pure Chemical Industries Co.) according to the manufacturer's protocol. cDNA was prepared from the extracted RNA by means of reverse transcription with Improm-II reverse transcriptase (Promega) and oligo(dT) primers according to the manufacturer's instructions. The cDNA was used for PCR amplification under the following conditions. Different sets of 
primers were designed and synthesized for PCR analysis of each gene. The primer pair used for amplifying OCTN2, 5'-TTTCGTGGGTGTGCTGATAGTCGC and 5'GTGGAAGGCGCAACAATCCCATT generated a $487 \mathrm{bp}$ OCTN2 PCR product. For ATB ${ }^{0,+}, 5^{\prime}$-AGGTGTGGGAATCACGATG and 5'-GTTCACTGGGAAGTTGTCCT generated a $296 \mathrm{bp} \mathrm{ATB}^{0,+}$ PCR product. PCR products were analyzed by agarose gel electrophoresis and visualized by staining with ethidium bromide.

\section{Analytical methods}

Cellular protein content was determined according to the method of Lowry et al. (1951) with bovine serum albumin as the standard. Cellular uptake was usually expressed as cell-to-medium ratio $(\mu \mathrm{l} / \mathrm{mg}$ protein), which was obtained by dividing the uptake amount ( $\mathrm{pmol} / \mathrm{mg}$ protein) by the concentration of test compound in the transport medium $(\mu \mathrm{M}=\mathrm{pmol} / \mu \mathrm{l})$.

The apparent kinetic parameters, $\mathrm{Km}$ and maximal transport rate (Vmax), of carnitine uptake by primary-cultured epididymal epithelial cells were estimated by non-linear regression curve fitting according to the following Michaelis-Menten type equations, where $v$ and $[s]$ are the velocity of substrate uptake and the substrate concentration respectively. In the case of a single saturable component, $\mathrm{v}=V_{\max } \times[\mathrm{s}] /(\mathrm{Km}+[\mathrm{s}])$ (equation 1) and for a system consisting of two saturable components, $\mathrm{v}=\mathrm{Vmax}_{1} \times[\mathrm{s}] /\left(K_{\mathrm{m}}+[\mathrm{s}]\right)+\mathrm{Vmax}_{2} \times$ $[\mathrm{s}] /\left(\mathrm{Km}_{2}+[\mathrm{s}]\right)$ (equation 2). The data were fitted to equation 2 with two saturable transport components, where the indices 1 and 2 indicate the high- and low-affinity components respectively. Non-linear regression analysis was performed using the MULTI program (Yamaoka et al. 1981). All data are expressed as means \pm S.E.M., and statistical analysis was performed with Student's $t$-test. The criterion of significance was taken to be $P<0.05$.

\section{Results}

\section{Time-course of $\left[{ }^{3} \mathrm{H}\right]$ carnitine uptake by primary- cultured epididymal epithelial cells}

$\left[{ }^{3} \mathrm{H}\right]$ Carnitine uptake by primary-cultured epididymal epithelial cells was measured over $60 \mathrm{~min}$ at $32.5^{\circ} \mathrm{C}$. Figure 1 shows that $\left[{ }^{3} \mathrm{H}\right]$ carnitine uptake increased linearly from $15 \mathrm{~min}$ to $60 \mathrm{~min}$. The uptake obtained by extrapolation of the data to time zero at $32.5^{\circ} \mathrm{C}$ was similar to the nonspecific binding of $\left[{ }^{3} \mathrm{H}\right]$ carnitine estimated by measuring uptake of $\left[{ }^{3} \mathrm{H}\right]$ carnitine for $1 \mathrm{~min}$ at $4^{\circ} \mathrm{C}$ (Fig. 1). To estimate non-saturable uptake of $\left[{ }^{3} \mathrm{H}\right]$ carnitine, uptake of $\left.{ }^{3} \mathrm{H}\right]$ carnitine in the presence of $20 \mathrm{mM}$ unlabeled excess carnitine was also examined. Unlabeled carnitine $(20 \mu \mathrm{M})$ significantly inhibited $\left[{ }^{3} \mathrm{H}\right]$ carnitine $(61 \mathrm{nM})$ uptake by epididymal epithelial cells to $1.33 \pm 0.13 \mu \mathrm{l} / \mathrm{mg}$ protein (Fig. 1). The observed carnitine uptake in the presence of $20 \mathrm{mM}$ unlabeled carnitine corresponded well with the

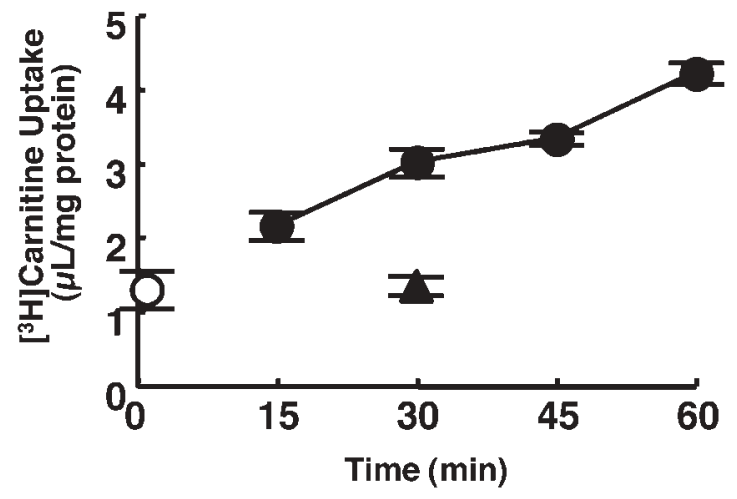

Figure 1 Time-courses of uptake of $\left[{ }^{3} \mathrm{H}\right]$ carnitine by rat primarycultured epididymal epithelial cells. The cells were preincubated for $20 \mathrm{~min}$ at $32.5^{\circ} \mathrm{C}$ in the transport buffer $(\mathrm{pH} 7.4)$. Uptake of $\left[{ }^{3} \mathrm{H}\right] \mathrm{car}-$ nitine $(61 \mathrm{nM})$ by rat primary-cultured epididymal epithelial cells in suspension was measured over $60 \mathrm{~min}$ in transport buffer $(\mathrm{pH} 7.4)$ at $32.5^{\circ} \mathrm{C}$ (solid circles). Non-specific binding of $\left[{ }^{3} \mathrm{H}\right]$ carnitine was estimated by measuring the uptake of $\left[{ }^{3} \mathrm{H}\right]$ carnitine for $1 \mathrm{~min}$ at $4{ }^{\circ} \mathrm{C}$ (open circle). Non-saturable uptake of $\left[{ }^{3} \mathrm{H}\right]$ carnitine for $30 \mathrm{~min}$ was estimated by measuring the uptake of $\left[{ }^{3} \mathrm{H}\right]$ carnitine in the presence of $20 \mathrm{mM}$ unlabeled carnitine at $32.5^{\circ} \mathrm{C}$ (solid triangle). Uptake is expressed as cell-to-medium ratio. Each result represents the mean \pm S.E.M. $(n=3$ or 4$)$.

non-specific binding of $\left[{ }^{3} \mathrm{H}\right]$ carnitine $(1.30 \pm 0.26 \mu \mathrm{l} / \mathrm{mg}$ protein), suggesting that non-saturable uptake of carnitine by epididymal epithelial cells was negligible. Accordingly, saturable uptake of carnitine for $30 \mathrm{~min}$ was estimated by subtracting the uptake of $\left[{ }^{3} \mathrm{H}\right]$ carnitine in the presence of $20 \mathrm{mM}$ unlabeled carnitine from the observed uptake in the following analysis.

\section{Sodium and concentration dependence of $\left.{ }^{3} \mathrm{H}\right]$ carnitine uptake by primary-cultured epididymal epithelial cells}

To characterize the saturable uptake systems for carnitine in epididymal epithelial cells, sodium dependence was examined. When sodium ion was replaced with $\mathrm{Li}^{+}, \mathrm{K}^{+}$or choline $^{+}$, uptake of carnitine was significantly decreased (Fig. 2). When sodium ion was replaced $\mathrm{N}$-methylglucamine, uptake of carnitine was also decreased from 2.65 to $1.14 \mu \mathrm{l} / \mathrm{mg}$ protein, which was comparable with the uptake in the presence of $20 \mathrm{mM}$ unlabeled carnitine $(1.33 \mu \mathrm{l} / \mathrm{mg}$ protein), showing that the sodium-independent carnitine transporter is negligible. Secondly, the concentration dependence of carnitine uptake by epididymal epithelial cells was measured in the range from $1 \mu \mathrm{M}$ to $3 \mathrm{mM}$ (Fig. 3). An Eadie-Hofstee plot for carnitine uptake by epididymal epithelial cells indicated the involvement of two saturable transport systems (Fig. 3B). Therefore, the data were fitted to equation 2, shown in Materials and Methods. The kinetic parameters were as follows: high-affinity transport system $\left(\mathrm{Km}_{1}=21.1 \pm 14.9 \mu \mathrm{M}\right.$, $\mathrm{Vmax}_{1}=19.1 \pm 13.7 \mathrm{pmol} / 30 \mathrm{~min}$ per $\mathrm{mg}$ protein) and low-affinity transport system $\left(\mathrm{Km}_{2}=2193 \pm 504 \mu \mathrm{M}\right.$, $V \max _{2}=2872 \pm 418 \mathrm{pmol} / 30 \mathrm{~min}$ per $\mathrm{mg}$ protein). 


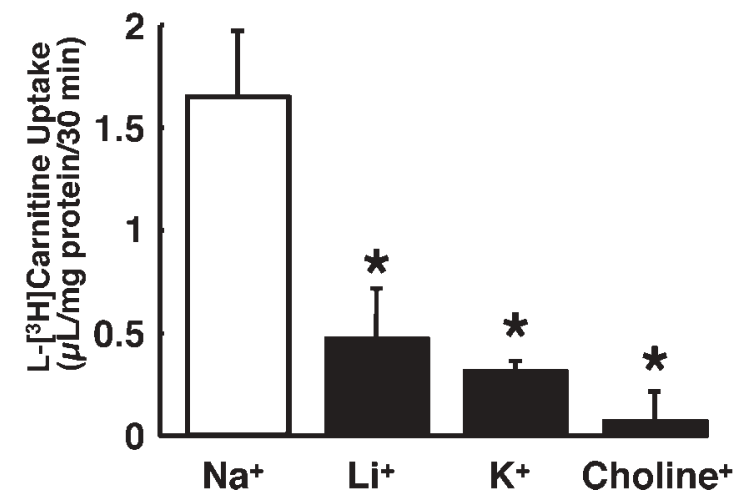

Figure 2 Sodium dependence of saturable $\left[{ }^{3} \mathrm{H}\right]$ carnitine uptake by rat primary-cultured epididymal epithelial cells. The cells were preincubated for $20 \mathrm{~min}$ at $32.5^{\circ} \mathrm{C}$ in the transport buffer $(\mathrm{pH} 7.4)$. Results show the saturable uptake of carnitine evaluated as observed uptake minus non-saturable uptake measured as the uptake of $\left[{ }^{3} \mathrm{H}\right]$ carnitine in the presence of $20 \mathrm{mM}$ unlabeled carnitine at $32.5^{\circ} \mathrm{C}$. Uptake of $\left[{ }^{3} \mathrm{H}\right]$ carnitine $(38 \mathrm{nM})$ by rat primary-cultured epididymal epithelial cells in suspension was measured for $30 \mathrm{~min}$ in transport buffer $(\mathrm{pH} 7.4)$ in the presence (open bar) or absence (solid bars) of $\mathrm{Na}^{+} . \mathrm{Na}^{+}$was replaced with lithium $\left(\mathrm{Li}^{+}\right)$, potassium $\left(\mathrm{K}^{+}\right)$and choline $\left(\right.$ Choline $\left.^{+}\right)$. Uptake is expressed as cell-to-medium ratio. Each result represents the mean \pm S.E.M. $(n=3$ or 4$) . * P<0.05$ compared with uptake in the presence of $\mathrm{Na}^{+}$.

\section{Evaluation of carnitine transporter expression with RT-PCR}

To identify the two saturable transport systems for carnitine, we examined the expression of carnitine transporters in epididymal epithelial cells by means of RT-PCR analysis. Based on the $\mathrm{Na}^{+}$dependence and $\mathrm{Km}$ values of epididymal carnitine transporters and the characteristics of previously reported carnitine transporters, we considered that the observed high- and low-affinity carnitine transport might be ascribed to OCTN2 and $\mathrm{ATB}^{0+}$ respectively. As shown in Fig. 4, the OCTN2 and $\mathrm{ATB}^{0,+}$ genes were expressed in all freshly isolated (day 0 ), preconfluent (day 3 ) and confluent cells (days 4 and 5). These results suggested that OCTN2 and $\mathrm{ATB}^{0,+}$ may be stably expressed in the cells during cultivation. OCTN3 and CT2, which are carnitine transporters expressed in male reproductive tissues in mice and human respectively (Tamai et al. 2000, Enomoto et al. 2002), seem not be important for transport of carnitine in rat epididymal epithelial cells, since no $\mathrm{Na}^{+}$-independent carnitine transport was detected, as shown in Fig. 2. The expression of these types of transporters in rat epididymal epithelial cells could not be examined, since the corresponding rat molecules have not yet been identified.

\section{Effect of various inhibitors on uptake of $\left[\mathrm{H}^{3}\right]$ carnitine by primary-cultured epididymal epithelial cells}

To clarify whether OCTN2 and ATB ${ }^{0,+}$ functionally contribute to carnitine uptake by epididymal epithelial cells, an inhibition study was conducted. Leucine and lysine
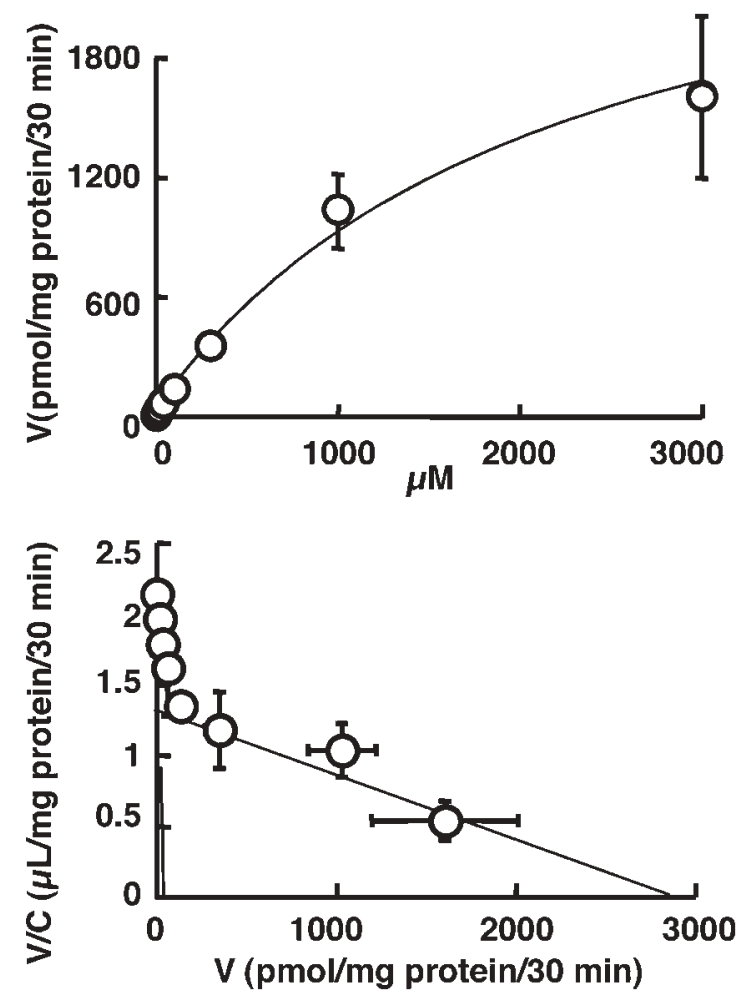

Figure 3 Concentration dependence of saturable uptake of $\left[{ }^{3} \mathrm{H}\right]$ carnitine in rat primary-cultured epididymal epithelial cells. Uptake of carnitine by rat primary-cultured epididymal epithelial cells in suspension was measured for $30 \mathrm{~min}$ in transport buffer $(\mathrm{pH} 7.4)$ at $32.5^{\circ} \mathrm{C}$. (A) Results show saturable uptake of carnitine evaluated as observed uptake minus non-saturable uptake measured as the uptake of $\left[{ }^{3} \mathrm{H}\right]$ carnitine in the presence of $20 \mathrm{mM}$ unlabeled carnitine at $32.5^{\circ} \mathrm{C}$. (B) An Eadie-Hofstee plot of the results is also shown. The solid line represents the uptake estimated from the kinetic parameters, $\mathrm{Km}$ and $\mathrm{Vmax}$, given in the Results. $\mathrm{V}$, uptake rate of carnitine (pmol/mg protein); C, concentration of carnitine $(\mu \mathrm{M}) ; \mathrm{V} / \mathrm{C}$, cell-to-medium ratio $(\mu \mathrm{l} / \mathrm{mg}$ protein). Each result represents the mean \pm S.E.M. $(n=3$ or 4$)$.

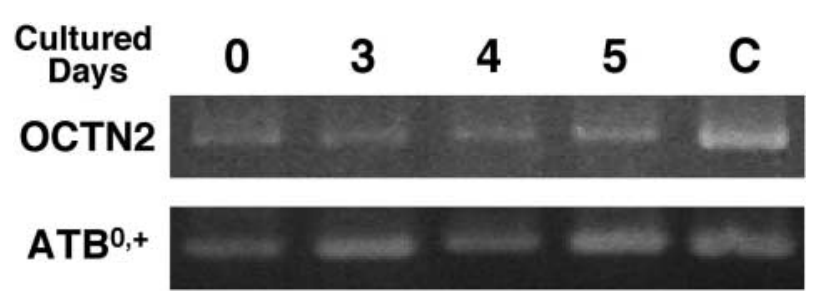

Figure 4 RT-PCR analysis for carnitine transporter expression in epididymal epithelial cells before and after cultivation. The specific primers described in Materials and Methods were used for determining expression of carnitine transporters in precultured epididymal epithelial cells ( 0 day) and primary-cultured epididymal epithelial cells (3, 4, and 5 days). cDNAs of kidney and colon were used as positive controls (C) of OCTN2 and $\mathrm{ATB}^{\mathrm{O},+}$ respectively. No signals were detected in samples without reverse transcription (data not shown) as negative controls. 
$(500 \mu \mathrm{M})$, which are inhibitors of $\mathrm{ATB}^{0,+}$ (Nakanishi et al. 2001, Umapathy et al. 2004), did not show any significant inhibitory effect (Table 1). In contrast, inhibitors of OCTN2 (Sekine et al. 1998, Tamai et al. 1998, 2000, Ohashi et al. 1999, 2001, Wu et al. 2000), cationic compounds (quinidine and pyrilamine) and carnitine analogues (acetylcarnitine, carnitine and $\gamma$-butyrobetaine) significantly inhibited carnitine transport by epididymal epithelial cells at $500 \mu \mathrm{M}$ (Table 1).

\section{Discussion}

Carnitine is concentrated in epididymal tissue and luminal fluid compared with plasma, and is a key nutrient for sperm maturation and motility. Furthermore, the presence of carnitine transport systems in epididymal epithelial cells has been reported (Yeung et al. 1980, James et al. 1981, Cooper et al. 1986, Radigue et al. 1996), though they have not been identified at the molecular level. Accordingly, in the present study, the carnitine transport system(s) in primary-cultured rat epididymal epithelial cells was characterized to identify the transporters that functionally contribute to carnitine transport in these cells.

Kinetic analysis indicated the presence of two types of carnitine transporters, a high-affinity transporter and a low-affinity transporter (Fig. 3). The $K \mathrm{~m}$ value of the highaffinity carnitine transporter $(21 \mu \mathrm{M})$ corresponds to that of OCTN2 (4-25 $\mu \mathrm{M}$; Tamai et al. 1998, Sekine et al.

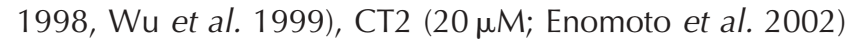
or OCTN3 (3 $\mu$ M; Tamai et al. 2000). OCTN2 and CT2 were found to be expressed in rat (Fig. 4; Rodrígez et al. 2002) and human (Enomoto et al. 2002) epididymal epithelial cells. The sodium dependence of the carnitine uptake observed in the present study suggested that OCTN2, which is an $\mathrm{Na}^{+}$-dependent carnitine transporter

Table 1 Inhibitory effect of various compounds $(500 \mu \mathrm{M})$ on saturable uptake of $\left[{ }^{3} \mathrm{H}\right]$ carnitine by rat epididymal epithelial cells. The cells were preincubated for $20 \mathrm{~min}$ at $32.5^{\circ} \mathrm{C}$ in the transport buffer $(\mathrm{pH} 7.4)$. Uptake of $\left[{ }^{3} \mathrm{H}\right]$ carnitine $(46 \mathrm{nM})$ by rat primarycultured epididymal epithelial cells in suspension was measured for 30 min in transport buffer $(\mathrm{pH}$ 7.4). Results are shown as a percentage of control uptake measured in the absence of inhibitors after subtracting the non-saturable uptake. Uptake is expressed as cell-to-medium ratio. Each result represents the mean \pm S.E.M. $(n=3$ or 4$)$.

\begin{tabular}{lc}
\hline & Relative uptake (\% of control) \\
\hline Control (no inhibitor) & $100 \pm 8.4$ \\
Amino acids & $83.6 \pm 10.1$ \\
$\quad$ Leucine & $97.5 \pm 13.5$ \\
$\quad$ Lysine & $59.2 \pm 7.5^{*}$ \\
Cationic compounds & $61.2 \pm 7.2^{*}$ \\
$\quad$ Pyrilamine & \\
$\quad$ Quinidine & $37.5 \pm 11.1^{*}$ \\
Carnitine analogues & $45.8 \pm 12.6^{*}$ \\
$\quad$ Acetylcarnitine & $71.2 \pm 5.7^{*}$ \\
$\quad$ Carnitine & \\
\hline -butyrobetaine &
\end{tabular}

$* P<0.05$ compared with control uptake.
(Tamai et al. 1998), is involved in the transport in epididymal epithelial cells, since OCTN3 and CT2 are not sodium ion dependent (Tamai et al. 2000, Enomoto et al. 2002). However, some contribution of CT2 and OCTN3 to epididymal carnitine transport from the cells to the lumen cannot be completely excluded, since expression of CT2 is limited to the apical membrane of epididymal epithelial cells (Enomoto et al. 2002) and carnitine uptake by epididymal cells was measured in suspension in the present study. It should be noted that rat homologues of CT2 and OCTN3 have not yet been identified.

Furthermore, $\left[{ }^{3} \mathrm{H}\right]$ carnitine uptake by epididymal epithelial cells was significantly inhibited by inhibitors of OCTN2 (Table 1). Under the conditions used where the substrate is $46 \mathrm{nM}$, the contributions of high- and low-affinity carnitine transporters, as estimated from the Vmax and $\mathrm{Km}$ values for each transporter, were about $40 \%$ and $60 \%$ of total saturable carnitine transport respectively. The reduction of uptake in the presence of inhibitors of OCTN2 is about $30-60 \%$ of that in the absence of inhibitors. It is a similar value to the contributions of the highaffinity carnitine transporter. These results suggested that OCTN2 mediates high-affinity transport of carnitine in rat epididymal epithelial cells.

Carnitine is accumulated in epididymal plasma and sperm. To accumulate carnitine in epididymal plasma, carnitine needs to cross the basolateral and apical membranes of epididymal epithelial cells. As the first step, uptake of carnitine should be mediated by a transporter existing at the basolateral membrane of epithelial cells. OCTN2 is localized at the basolateral membrane of epididymal epithelial cells in rats (Rodrígez et al. 2002), and was functional in primary-cultured epididymal epithelial cells as demonstrated in this study. In addition, genetically OCTN2-deficient jvs mice are infertile, with epididymal dysfunction (Toshimori et al. 1999). These results strongly suggest that OCTN2 is functional and essential for carnitine transport at the basolateral membrane of the epididymis.

$\mathrm{ATB}^{0,+}$, a low-affinity $(K \mathrm{~m}=0.83 \mathrm{mM}), \mathrm{Na}^{+}$-dependent carnitine transporter (Nakanishi et al. 2001), was also detected in epididymal epithelial cells by RT-PCR (Fig. 4). However, the observed effect of $\mathrm{ATB}^{0,+}$ inhibitors did not support the involvement of $\mathrm{ATB}^{0,+}$, though a low-affinity transporter contributed about $60 \%$ of total saturable carnitine uptake. These results suggested that $\mathrm{ATB}^{\mathrm{O},+}$ does not functionally contribute to carnitine transport into epididymal epithelial cells. Therefore, the low-affinity carnitine transporter existing in epididymal epithelial cells seems not to be a known transporter.

Carnitine movement into the caput or corpus epididymis is higher than that into the distal part of the tissue (Bohmer et al. 1979, Yeung et al. 1980, Setchell \& Hinton 1981), suggesting that there is a regional difference in the carnitine transport activity in epididymis. However, in the present study we prepared the cells from whole epididymal tissues. Further studies on the regional difference in 
carnitine transport activity will be important to clarify the roles of carnitine transporters in the maturation of spermatozoa.

In conclusion, the present study shows that OCTN2 is functional as a carnitine transporter in epididymal epithelial cells, and that a molecularly unidentified low-affinity carnitine transporter also exists in epididymal epithelial cells. Molecular identification of carnitine transporters localized at the apical membrane of epididymal epithelial cells, and also of the low-affinity carnitine transporter found in this study, will be important to completely understand the mechanism of control of carnitine concentration in epididymal tissues.

\section{Acknowledgements}

The authors declare that there is no conflict of interest that would prejudice the impartiality of this scientific work. This investigation was funded in part by a Grant-in-Aid for Scientific Research from the Ministry of Education, Japan.

\section{References}

Bohmer T, Sar M, Stumpf WE \& Hansson V 1979 Autoradiographic study of the $\left[{ }^{3} \mathrm{H}\right]$ carnitine distribution in rat epididymis. International Journal of Andrology 2 62-73.

Bremer J 1983 Carnitine-metabolism and functions. Physiological Reviews 63 1420-1480.

Brooks DE, Hamilton DW \& Mallek AH 1974 Carnitine and glycerylphosphorylcholine in the reproductive tract of the male rat. Journal of Reproduction and Fertility 36 141-160.

Casillas ER 1972 The distribution of carnitine in male reproductive tissues and its effect on palmitate oxidation by spermatozoal particles. Biochimica et Biophysica Acta $280545-551$.

Casillas ER \& Chaipayungpan S 1979 The distribution of carnitine and acetylcarnitine in the rabbit epididymis and the carnitine content of rabbit spermatozoa during maturation. Journal of Reproduction and Fertility 56 439-444.

Cooper TG, Gudermann TW \& Yeung CH 1986 Characteristics of the transport of carnitine into the cauda epididymidis of the rat as ascertained by luminal perfusion in vitro. International Journal of Andrology 9 348-358.

Enomoto A, Wempe MF, Tsuchida H, Shin HJ, Cha SH \& Anzai N et al. 2002 Molecular identification of a novel carnitine transporter specific to human testis. Journal of Biological Chemistry 277 36262-36271.

Hinton BT \& Palladino MA 1995 Epididymal epithelium: its contribution to the formation of a luminal fluid microenvironment. Microscopy Research and Technique 30 67-81.

Hinton BT, Snoswell AM \& Setchell BP 1979 The concentration of carnitine in the luminal fluid of the testis and epididymis of the rat and some other mammals. Journal of Reproduction and Fertility $\mathbf{5 6}$ 105-111.

Hinton BT, Brooks DE, Dott HM \& Setchell BP 1981 Effects of carnitine and some related compounds on the motility of rat spermatozoa from the caput epididymidis. Journal of Reproduction and Fertility 61 59-64.

Hinton BT, Palladino MA, Rudolph D \& Labus JC 1995 The epididymis as protector of maturing spermatozoa. Reproduction, Fertility, and Development 7 731-745.

James MJ, Brooks DE \& Snowsell AM 1981 Kinetics of carnitine uptake by rat epididymal cells. FEBS Letters 126 53-56.
Jeulin C \& Lewin LM 1996 Role of free L-carnitine and acetyl-L-carnitine in post-gonadal maturation of mammalian spermatozoa. Human Reproduction Update 2 87-102.

Kato R, Maeda T, Akaike T \& Tamai I 2005 Nucleoside transport at the blood-testis barrier studied with primary-cultured Sertoli cells. Journal of Pharmacology and Experimental Therapeutics 312 601-608.

Kierszenbaum AL, Lea O, Petrusz P, French FS \& Tres LL 1981 Isolation, culture, and immunocytochemical characterization of epididymal epithelial cells from pubertal and adult rats. PNAS 78 1675-1679.

Kobayashi D, Goto A, Maeda T, Nezu J, Tsuji A \& Tamai I 2005 OCTN2-mediated transport of carnitine in isolated Sertoli cells. Reproduction 129 729-736.

Leung GP, Ward JL, Wong YD \& Tse CM 2001 Characterization of nucleoside transport systems in cultured epididymal epithelium. American Journal of Physiology $\mathbf{2 8 0}$ C1076-C1082.

Lowry OH, Rosebrough NJ, Farr AL \& Randall RJ 1951 Protein measurement with the Folin phenol reagent. Journal of Biological Chemistry $193265-275$.

Marquis NR \& Fritz IB 1965 Effects of testosterone on the distribution of carnitine, acetyl carnitine and carnitine acetyltransferase in tissues of the reproductive system of the male rat. Journal of Biological Chemistry $2402197-2200$.

Matalliotakis I, Koumantaki Y, Evageliou A, Matalliotakis G, Goumenou A \& Koumantakis E 2000 L-Carnitine levels in the seminal plasma of fertile and infertile men: correlation with sperm quality. International Journal of Fertility and Women's Medicine 45 $236-240$

Nakanishi T, Hatanaka T, Huang W, Prasad PD, Leibach FH, Ganapathy ME \& Ganapathy V $2001 \mathrm{Na}^{+}$- and $\mathrm{Cl}^{-}$-coupled active transport of carnitine by the amino acid transporter $\mathrm{ATB}^{\mathrm{O},+}$ from mouse colon expressed in HRPE cells and Xenopus oocytes. Journal of Physiology 532 297-304.

Nezu J, Tamai I, Oku A, Ohashi R, Yabuuchi H \& Hashimoto $\mathbf{N}$ et al. 1999 Primary systemic carnitine deficiency is caused by mutations in a gene encoding sodium ion-dependent carnitine transporter. Nature Genetics 21 91-94.

Ohashi R, Tamai I, Yabuuchi H, Nezu J, Oku A, Sai Y, Shimane M \& Tsuji A $1999 \mathrm{Na}^{+}$-dependent carnitine transport by organic cation transporter (OCTN2): its pharmacological and toxicological relevance. Journal of Pharmacology and Experimental Therapeutics $291778-784$.

Ohashi R, Tamai I, Nezu J, Nikaido H, Hashimoto N \& Oku A et al. 2001 Molecular and physiological evidence for multifunctionality of carnitine/organic cation transporter OCTN2. Molecular Pharmacology 59 358-366.

Radigue C, Es-Slami S \& Soufir JC 1996 Relationship of carnitine transport across the epididymis to blood carnitine and androgens in rats. Archives of Andrology 37 27-31.

Rodrígez CM, Labus JC \& Hinton BT 2002 Organic cation/carnitine transporter, OCTN2, is differentially expressed in the adult rat epididymis. Biology of Reproduction 67 314-319.

Sekine T, Kusuhara H, Utsunomiya-Tate N, Tsuda M, Sugiyama $\mathbf{Y}$, Kanai Y \& Endou H 1998 Molecular cloning and characterization of high-affinity carnitine transporter from rat intestine. Biochemical and Biophysical Research Communications 251 586-591.

Setchell BP \& Hinton BT 1981 The effects on the spermatozoa of changes in the composition of luminal fluid as it passes along the epididymis. Progress in Reproductive Biology 8 58-66.

Tamai I, Ohashi R, Nezu J, Yabuuchi H, Oku A, Shimane M, Sai Y \& Tsuji A 1998 Molecular and functional identification of sodium ion-dependent, high affinity human carnitine transporter OCTN2. Journal of Biological Chemistry $27320378-20382$.

Tamai I, Ohashi R, Nezu J, Sai Y, Kobayashi D, Oku A, Shimane M \& Tsuji A 2000 Molecular and functional characterization of organic cation/carnitine transporter family in mice. Journal of Biological Chemistry 275 40064-40072.

Tamai I, China K, Sai Y, Kobayashi D, Nezu J, Kawahara E \& Tsuji A $2001 \mathrm{Na}^{+}$-coupled transport of L-carnitine via high-affinity 
carnitine transporter OCTN2 and its subcellular localization in kidney. Biochimica et Biophysica Acta 1512 273-284.

Toshimori K, Kuwajima M, Yoshinaga K, Wakayama T \& Shima K 1999 Dysfunctions of epididymis as a result of primary carnitine deficiency in juvenile visceral steatosis mice. FEBS Letters $\mathbf{4 4 6}$ $323-326$.

Umapathy NS, Ganapathy V \& Ganapathy ME 2004 Transport of amino acid esters and the amino-acid-based prodrug balganciclovir by the amino acid transporter ATB $^{0,+}$. Pharmaceutical Research $\mathbf{2 1}$ $1303-1310$.

Vicari E \& Calogero AE 2001 Effects of treatment with carnitines in infertile patients with prostato-vasiculo-epididymitis. Human Reproduction 16 2338-2342.

Wu X, Huang W, Prasad PD, Seth P, Rajan DP \& Leibach FH 1999 Functional characteristics and tissue distribution pattern of organic cation transporter 2 (OCTN2), an organic cation/carnitine transporter. Journal of Pharmacology and Experimental Therapeutics 290 $1482-1492$.

Wu X, George RL, Huang W, Wang H, Conway SJ, Leibach FH \& Ganapathy V 2000 Structural and functional characteristics and tissue distribution pattern of rat OCTN1, an organic cation transporter, cloned from placenta. Biochimica et Biophysica Acta 1466 $315-327$.
Yabuuchi H, Tamai I, Nezu J, Sakamoto K, Oku A, Shimane M, Sai Y \& Tsuji A 1999 Novel membrane transporter OCTN1 mediates multispecific, bi-directional, and pH-dependent transport of organic cations. Journal of Pharmacology and Experimental Therapeutics 289 768-773.

Yamaoka K, Tanigawara Y, Nakagawa T \& Uno T 1981 A pharmacokinetic analysis program (MULTI) for microcomputer. Journal of Pharmacobio-dynamics 4 879-885.

Yeung CH, Cooper TG \& Waites GMH 1980 Carnitine transport into the perfused epididymis of the rat: regional differences, stereospecificity, stimulation by choline, and the effect of other luminal factors. Biology of Reproduction 23 294-304.

Yokogawa K, Higashi $\mathbf{Y}$, Tamai I, Nomura $M$, Hashimoto $\mathbf{N} \&$ Nikaido H 1999 Decreased tissue distribution of L-carnitine in juvenile visceral steatosis mice. Journal of Pharmacology and Experimental Therapeutics 289 224-230.

Received 23 March 2005

First decision 24 May 2005

Revised manuscript received 10 August 2005

Accepted 19 August 2005 